\title{
Improving the Critical Thinking Skills and Responsibility Character of Students with Blended Learning Based on Tri Hita Karana
}

\author{
Ni Putu Sri Ratna Dewi ${ }^{* 1}$, Putu Budi Adnyana ${ }^{1}$, Desak Made Citrawathi ${ }^{1}$, \\ I Made Oka Riawan and I Made Citra Wibawa ${ }^{2}$
}

\author{
${ }^{I}$ Department of Biology and Marine Fisheries, Faculty of Mathematic and Natural Science, Ganesha University of \\ Education, Buleleng, Bali. \\ ${ }^{2}$ Department of Primary School Teacher Education, Faculty of Science Education, Ganesha University of Education, \\ Buleleng, Bali. \\ ${ }^{*}$ Corresponding author, Email: ratna.dewi@undiksha.ac.id
}

\begin{abstract}
This study aimed to determine the differences in critical thinking skills and the character of student responsibility between those taught by Blended Learning based on Tri Hita Karana (THK) and the conventional method. This study was a quasi-experimental with a post-test only non-equivalent control group design. The subjects in this study were student of the Biology and Marine fisheries Department for the 2019/2020 academic year. The object of this study was the Critical thinking skills and the character of student responsibility. The number of samples used in this study was 48 students. The data collection methods used were test and questionnaire method. The critical thinking test instrument was the tool to collect the data on critical thinking skills, while the responsibility character data were collected using a questionnaire. Based on the results of data analysis, there was a significant difference between the critical thinking skills and the responsibility character of student taught by Tri Hita Karana-based blended learning, and students taught conventionally. The Blended Learning method was preferable to the conventional method.
\end{abstract}

Keywords: Blended Learning, Tri Hita Karana, Critical Thinking Skills, Responsibility Character

\section{INTRODUCTION}

Indonesia is currently experiencing significant changes in all aspects of life. One vital point that shifted significantly is education. Under the leadership of Mr. Nadiem Makarim, The Ministry of Education and Culture (Kemendikbud) changes the strategy to improve the quality of the nation's generation. This idea aims to form a creative generation in applying the knowledge gained in the educational process and able to provide solutions to problems that occur in the surrounding environment. The changes focus on three indicators; numeracy, literacy, and improving character. Firstly numeracy is increasing mastery related to numbers. Secondly, literacy means the ability to analyze readings and find meaning from reading. The last is improving character is learning based on the concept of diversity (Bhinneka). The transformation has always been executing in keeping up with the changing needs of the world today. The descendants of the nation should be prepared to face competition in the digital era by increasing the three indicators mentioned above [1].

Nowadays, education implementation has a purpose to assist scholars with various learning experiences. It will make them understand and take advantage of mainstream information. They can also think critically and analyze every opportunity that can occur based on the values of Pancasila. Educators and students at all levels of qualifications, in elementary schools, secondary schools, and universities must prepare themselves to carry out an effective learning process in this 21st-century. This learning style emphasizes six things, specifically: 1) core subject knowledge; 2) development of learning skills; 3) utilize 21st-century learning media to develop learning skills; 4) teaching students in the context of the 21 st- 
century; 5) teaching 21st-century content; and 6) using 21 st-century assessments that measure 21 st-century skills [2]. The 21st-century learning aims to make students have mastery of $4 \mathrm{C}$, namely: Communication, Collaboration, Critical thinking, and Creative [3].

Higher education is one of the educational institutions that have the authority to determine the curriculum and education delivery. It means that a university can immediately evaluate and adjust the curriculum according to the demands of the world of work where the graduates of the institution will be absorbed or used. What higher education can do is evaluate the curriculum so that it produces a more innovative learning system that has an orientation towards increasing student abilities in the aspects of data literacy, technological literacy, and human literacy. For this reason, the learning system carried out in tertiary institutions is expected to start leading to digital learning. Implementing these changes requires plenty of time, effort, and costs to achieve the goals. To address this, one thing that can be done is to carry out blended learning. Blended learning is one of the most effective methods where students in this era are the millennial generation who is inseparable with gadgets. Blended learning is one of the most effective learning methods where students in this era are the millennial generation who cannot be separated from gadgets. Blended learning as a combination of face-to-face and online learning [4]. Blanded learning is a learning method that combines face-to-face learning with web-based learning [5]. On the other side, Garn ham said that blended learning is an approach that integrates faceto-face teaching and computer-assisted instructional activities (computer-mediated instruction) in a pedagogic environment. The most common definition of blended learning is learning that combines face-to-face learning and computer-based learning (online and offline) [6]. Thus the application of blended learning can help educators meet the demands of the digitalization era. This is one of the main aspects of modern education reform, with blended learning helping to personalize education, and enabling students to be more productive. Ganesha University of Education (Undiksha) is one of the leading tertiary education institutions in the province of Bali. Undiksha has a vision "to become a superior university based on the Tri Hita Karana philosophy in ASIA in 2045". The inclusion of philosophy Tri Hita Karana (THK) in Undiksha's vision has implications for efforts to develop policies for implementing the Tri Dharma of Tertiary Education at Ganesha University of Education. One of them is in the field of implementing education as one of the Tri Dharma of Higher Education. The vision of the Ganesha University of Education has implications for the innovation of learning development based on the THK philosophy. THK-based learning development is influential to do, in addition to the demands of the vision of the university, it is also a factual demand for a multicultural Indonesian society. The values contained in the THK philosophy are universal and can be used as a foundation in creating a sense of life that is comfortable, serene, and peaceful both physically and naturally [7]. philosophy Tri Hita Karana instructs us to maintain a harmonious relationship with the creator, nature, and fellow humans. In this case, learning based on THK can be used as a means of building a good personality for students. The THK-based study can foster a sense of awareness and a sense of responsibility for the welfare of themselves and the environment, facilitating the growth and development of the potential of students, particularly the ability to use thoughts and words, and actions to create works. These three potentials continue to be generated and reflected into skills and competencies which are the focus of 21 st-century learning. In implementing this learning process, Undiksha has provided great services for students, one of which is by providing free $\mathrm{Wi}-\mathrm{Fi}$ in the campus area. As a result, students can connect to the internet anytime. This action provides a good opportunity for blended learning to be conducted so that students can use their smartphones positively in the learning process. Many Undiksha lecturers have implemented blended learning in several courses but the implementation of THK-based blended learning is still rare, even though the emanation of educational values contained in the THK provides a strong attraction for education providers to raise it as a source of inspiration in the process improving the quality of education to achieve quality and character output. Personal qualities, namely responsibility, morale, character, integrity, self-confidence, and loyalty will grow well as part of the fundamental skills of educated students in an educational environment based on THK [8]. The ability of humans to adapt to the surroundings to maintain their survival is very dependent on their ability to think. A person who has good high-order thinking skills (critical and creative thinking) will be able to analyze the situation and can make predictions of the impact that will occur, also, to make logical problem-solving. The results of observations carried out in August 2019 showed that most students were not yet capable of making satisfied practicum reports. There were still many practicum data that they got but not included in the discussion. The average score of student practicum reports was still low, namely 67 . Students have not been able to interpret data from practicum results, make a connection between the data obtained with the purpose of practicum, build indepth discussions, or logical reasons regarding findings or lab results. There were still many practicum data missed without being included in the study because the ability to do induction and deduction was still lacking. Students are less critical in responding or responding to data from practicum results, less able to link the theoretical basis with the results obtained. For this reason, it is necessary to research the implementation of THK-based blended learning to improve critical thinking skills and the responsibility character, because of several things. First, THK-based blended learning provides more opportunities for students to find information or material in their way, besides the involvement in the learning provided is more varied, offers many alternative learning sources for students beyond the materials provided. Second, the availability of Wi-Fi/hotspot networks in campus environments with stable speeds can help all members of the community in the Undiksha environment, both 
lecturers and students. Third, students afford to have laptops and Android phones to support their work. It shows that there are facilities available for technical support for implementing blended learning. Based upon the above, the formulation of the problem to be solved in this study is whether there are differences in critical thinking skills and the character of student responsibility between those taught with THK-based blended learning and those taught conventional method.

\section{METHODOLOGY}

This research was a quasi-experimental design with a posttest only Non-Equivalent Control Group Design. The setting of study was the Department of Biology and Marine Fisheries Education, Faculty of Mathematics and Natural Sciences, Ganesha University of Education. THKbased blended learning was applied to human anatomy and physiology subjects, especially reproductive system material. ri-hita karana-based blended learning in this study was conducted with two face-to-face meetings and 3 online meetings. philosophy Tri Hita Karana which is integrated in this research is the megedong-gedongan ceremony. This ceremony is a ceremony performed on women who are 7 months pregnant. his ceremony is closely related to the condition of the reproductive organs that students learn on the reproductive system material.

\subsection{Population and Sample}

The population in this study were undergraduate students majoring in Biology and Marine Fisheries Education for the academic year of 2019/2020. The sample involved in this research was 36 students of the 6th semester of the Biology Education study program.

\subsection{Data Collection Technique}

The data in this study were students' critical thinking skills and student responsibility character data. critical thinking data was collected using the test method, while the responsibility characters data was collected using a questionnaire procedure.

\subsection{Research Instrument}

This study used two instruments, namely one instrument to determine students' critical thinking skills and one to specify the character of student responsibility, which had been tested for its validity and reliability coefficient [9]. The critical thinking test used consists of 6 indicators [10]. The number of questions in the critical thinking ability test used was 14 items. The responsibility character questionnaire used consists of 5 indicators by a total of 10 inquiries.

\subsection{Data Analysis Technique}

Descriptive and statistic were the methods to analyse the data obtained. The data descriptively analysed the mean value and standard deviation. Statistically, the data were tested using the independent sample t-test. Before performing data analysis, it was required to examine them for normality and homogeneity firstly.

\section{RESULTS AND DISCUSSION}

The study object was the capability to think critically and the character of student responsibility as a result of the treatment between learning approaches. The learning approaches in this study were the Tri Hita Karana-based blended learning strategy and the conventional learning strategy.

\subsection{Result}

The data in this study had four categories, there were critical thinking skills scores of students who took Tri Hita Karana based blended learning, the critical thinking skills scores of students who took the conventional approach, the character scores of student responsibility with Tri Hita Karana-based blended learning, and the point of the responsibility personality of students who took conventional approach. The average score data of the critical thinking skills, the responsibility characters of students and the results of the Independent sample t-test analysis had been illustrated in Table 1 .

Table 1. Summary of the Average Score of Critical Thinking Ability and Characteristics of Student Responsibilities

\begin{tabular}{|l|c|c|}
\hline Average Scores & $\begin{array}{c}\text { Experimental } \\
\text { Class }\end{array}$ & $\begin{array}{c}\text { Control } \\
\text { Class }\end{array}$ \\
\hline $\begin{array}{l}\text { Critical Thinking } \\
\text { Ability }\end{array}$ & 72.47 & 51.67 \\
\hline $\begin{array}{l}\text { Responsibility } \\
\text { Character }\end{array}$ & 68.53 & 56.56 \\
\hline
\end{tabular}

Here was the bar chart of the average scores of critical thinking skill and characteristics of student responsibilities on illustration in Figure 1. 
the average value of critical thinking

skills and the character of student responsibility

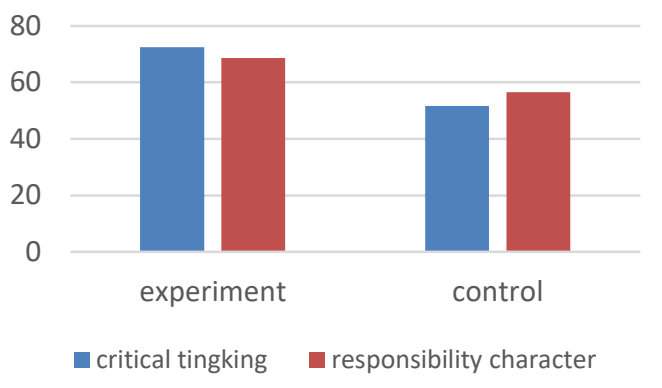

Figure 1. The bar chart of average scores of critical thinking skills and student responsibility character

\subsection{Discussion}

The implementation of Tri Hita Karana-based blended learning in learning reproductive system material showed significant differences in critical thinking skills and the character of students' responsibility between those taught with Tri Hita Karana-based blended learning and those taught conventionally. The results of the data analysis of critical thinking skills showed that the group that took the Tri Hita Karana based blended learning had an average score of 72.47; while the other group with conventional learning had an average score of 51.67. The data analysis also showed that the group with blended learning based on Tri Hita Karana had an average responsibility character score of 68.53; while another group of students who took conventional approach had an average responsibility character score of 56.56. It showed that the critical thinking skills and responsibility personality of students who studied with Tri Hita Karana-based blended learning were one step ahead of those taught conventionally.

The empirical theory proved that Tri Hita Karana-based blended learning could improve the critical thinking skills and the character of student responsibility. The main cause of this result was because the combination of face-to-face and online study provided a varied experience and allowed students to find knowledge anytime, anywhere, and on their way. The Google Classroom application helped this blended learning and allowed students to experience new technology during the learning process. Face-to-face activities provided opportunities for students to socialize and communicate their independent learning outcomes in a presentation. On this occasion, the weakness in online learning could be resolved.

Blended learning in this investigation used eight steps, namely: prepare me, tell me, show me, let me, coach me, connect me, support me, and check me. It integrated with the Balinese Traditional ceremony "Megedong-gedongan" which was full of meaning and was one of the philosophy manifestations of the Tri Hita Karana, especially in terms of maintaining harmony with fellow humans. Magedong- gedongan ceremony had integration into the material of the human reproductive system. Each learning step provided a broad opportunity for students to develop indicators of critical thinking and character of responsibility. Students became more active in seeking and building knowledge in themselves and were more aware of their duties and responsibilities as individuals who were learning. The variety of material forms used in Google Classroom made students fascinated to read and understand the material. The material design used in this research was LKM and tutorial video.

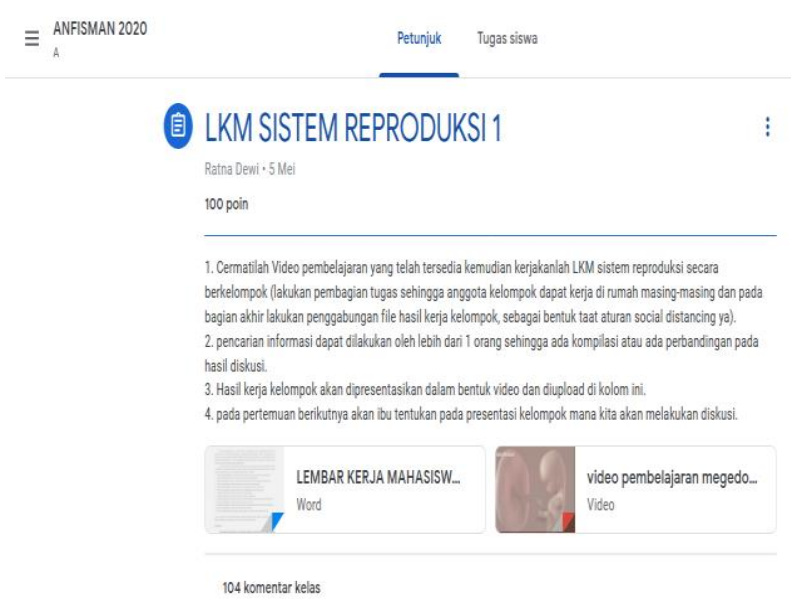

Figure 2. Material Design Presented on Google Classroom

This research was in line as claimed on reff [11] that Tri Hita Karana-oriented blended learning could improve student's critical thinking ability. She said that in every step of blended learning, students were allowed to find information in their way and to make decisions systematically. With the THK orientation, the students were trained to examine the relationship between culture in society with theoretical truth using the scientific method. Besides, the interviews and video documentation assignments required students to formulate questions that gave directions to get the answers, carried out investigations/data collection, made logical deductions, delivered opinions with reasons that were following the concept or theory, and evaluated what to do based on the facts. The strict timing of the Google Classroom application, especially when submitting assignments, provided an opportunity for students to be aware of their tasks and obligations to do their projects as well as possible so that they could collect them on time. There were several types of student assignment bills in THKbased blended learning that could be seen in Figure 3 . 


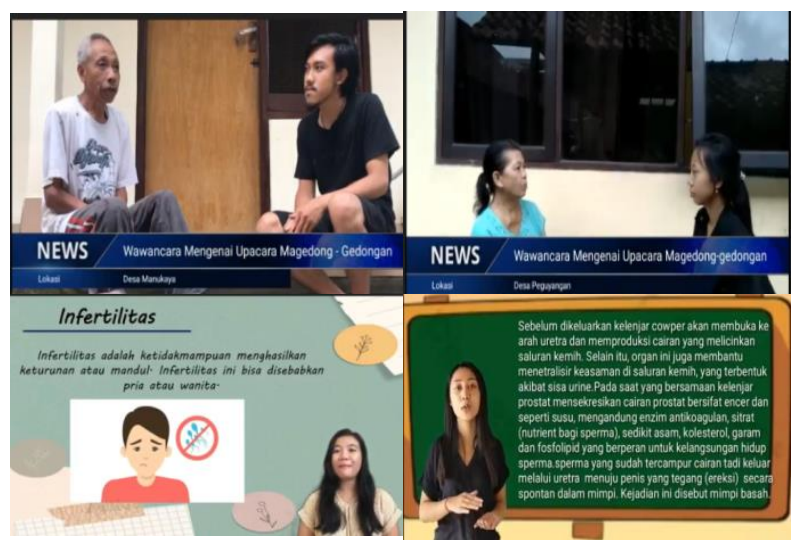

Figure 3. Several Documentations of Students Activities on Google Classroom

The complexity of the learning steps that students went through, the various forms of material presented, and the variety of assignments given in the Tri Hita Karana based blended study, made the critical thinking skills and responsibility character of students developing very well. Empirically, it was proven by a significant difference between students' critical thinking skills and the character of student responsibility between those taught with THKbased blended learning and those studied with the conventional method.

The results of this study were in line with other research, including the research conducted on reff [12] namely "Blended Learning in Biology Learning Can Improve Critical Thinking Skills." Critical thinking skills and process skills in the learning cycle $7 \mathrm{e}$ based on local wisdom. The Effect Of Blended Learning And Motivation Learning Models Learning On Student Learning Outcomes [13].

\section{CONCLUSION}

a) There was significant differences in critical thinking skills between those taught with Tri Hita Karana-based blended learning and those taught conventionally.

b) The character of students' responsibility was improving remarkably when they studied using the Tri Hita Karana-based blended learning. Meanwhile, the students who studied using the conventional approach did not show any significant improvement.

\section{ACKNOWLEDGMENTS}

The author would like to thank the Head of The Biology and Marine Fisheries Department who provided the opportunity to conduct this research, the team of research, the validator and fellow lecturers of the Biology Education Study Program at the Ganesha University of Education who helped in completing this research.

\section{REFERENCES}

[1] L. J. Harrison, S. McLeod, D. Berthelsen, S. Walker. Literacy, numeracy, and learning in schoolaged children identified as having speech and language impairment in early childhood. International Journal of Speech-Language Pathology, 11 (5) (2009) 392-403. DOI: https://doi.org/10.1080/17549500903093749

[2] J. Nouri, L. Zhang, L. Mannila, E. Norén. Development of computational thinking, digital competence and 21 st century skills when learning programming in K-9. Education Inquiry, 11 (1) (2020) 1-17. DOI: https://doi.org/10.1080/20004508.2019.162 7844

[3] M. A. R. Pratama, E. Cahyono, Y. U. Aggraito. Implementation of problem based learning model to measure communication skills and critical thinking skills of Junior High School Students. Journal of Innovative Science Education, 8 (3) (2019) 324-331. DOI: $10.15294 /$ JISE.V8I1.30788

[4] I. Shibley, K. E. Amaral, J. D. Shank, L. R. Shibley. Designing a blended course: Using ADDIE to guide instructional design. Journal of College Science Teaching, 40 (6) (2011) 66-70.

[5] T. Yigit, A. Koyun, A. S. Yuksel, I. A. Cankaya. Evaluation of blended learning approach in computer engineering education. Procedia-Social and Behavioral Sciences, 141 (2014) 807-812. DOI: https://doi.org/10. 1016/j.sbspro.2014.05.140

[6] M. Oliver, K. Trigwell. Can 'blended learning'be redeemed?. E-learning and Digital Media, 2 (1) (2005) 17-26. DOI: https://doi.org/10.2304/elea.2005.2.1.17

[7] A. T. Atmadja, S. Saputra, A. K. Komang. The Effect Of Emotional Spiritual Quotient (ESQ) To Ethical Behavior In Accounting Profession With Tri Hita Karana Culture's As A Moderating Variable .Research Journal of finance and Accounting, 5 (7) (2014) 187-197.

[8] N. K. S. Kusuma Wardhani, N. W. Karmini, I. P. Sastra Wibawa. Tri Hita Karana-Oriented Education as An Effort to Integrate Environmental Education in Bali High Schools. Talent Development \& Excellence, 12 (1) (2020) 5-10. 
[9] C. Pop, B. Khampirat. Self-assessment instrument to measure the competencies of Namibian graduates: Testing of validity and reliability. Studies in Educational Evaluation, 60 (2019) 130-139. DOI: https ://doi.org/10.1016/j.stueduc.2018.12.004

[10] W. Techataweewan, U. Prasertsin. Development of digital literacy indicators for Thai undergraduate students using mixed method research. Kasetsart Journal of Social Sciences, 39 (2) (2018) 215-221. DOI: https://doi.org/10.1016/j.kjss.2017.07.001

[11] M. Adityanandana, J. E. Gerber. Post-growth in the tropics? Contestations over Tri Hita Karana and a tourism megaproject in Bali. Journal of Sustainable Tourism, 27 (12) (2019) 1839-1856. DOI: https://doi.o $\mathrm{rg} / 10.1080 / 09669582.2019 .1666857$

[12] H. Husamah. Blended project based learning: thinking skills of new students of biology education department (environmental sustainability perspective) .Jurnal Pendidikan IPA Indonesia, 4 (2) (2015) 110119.

[13] Y. W. Lin, C. L. Tseng, P. J. Chiang. The effect of blended learning in mathematics course. EURASIA Journal of Mathematics, Science and Technology Education, 13 (3) (2016) 741-770. DOI: https://doi.org/ 10.12973/eurasia.2017.00641a 